UDK: 929YAN J.:7

COPYRIGHT (): MATIC URBANIJA

\title{
Yan Jun: od pesnika do zvočnega umetnika
}

\author{
Matic URBANIJA*
}

\section{Izvleček}

Namen pričujočega članka je raziskati umetniški razvoj vidnega predstavnika glasbene eksperimentalne scene v Pekingu, Yan Juna, ki ga lahko razumemo le skozi pogled na njegovo predhodno življenje, preden je postal zvočni umetnik. Članek postavlja v ospredje tudi njegove etične principe, ki so vodilni v vseh njegovih prizadevanjih. Ekperimentalna glasbena scena na Kitajskem je iz znanstvenega vidika neraziskana in raziskovalcev tega področja skoraj ni, zato sta primarna vira informacij dva intervjuja z Yan Junom decembra 2010 in maja 2011.

Ključne besede: Yan Jun, zvočna umetnost, eksperimentalna glasba, podzemlje, svoboda

\begin{abstract}
The purpose of this article is to research the artistic development of a sound artist, Yan Jun, which cannot be understood without his previous life before he became a sound artist. The article also puts forward Yan Jun's ethical principles which are leading principles in all his endeavors. The experimental music scene in China is, from an academic point of view, under-researched and researches in this field are almost nonexistent. Therefore, the primary source of information are two interviews made with Yan Jun in December 2010 and May 2011.
\end{abstract}

Keywords: Yan Jun, sound art, experimental music, underground, freedom

\footnotetext{
* Matic Urbanija, doktorski študent na Oddelku za azijske in afriške študije Filozofske fakultete Univerze v Ljubljani. E-mail: matic.urbanija@gmail.com
} 


\section{Uvod}

Namen pričujočega članka je raziskati umetniški razvoj vidnega predstavnika glasbene eksperimentalne scene $\mathrm{v}$ Pekingu, Yan Juna. Poleg njegove zvočne umetnosti je v razpravo zajeto tudi njegovo predhodno življenje, se pravi obdobje, ko še ni ustvarjal zvočne umetnosti. Že od mladih let naprej je zelo intenzivno povezan z glasbo, bodisi v vlogi pesnika, glasbenega kritika, glasbenega založnika ali pa organizatorja rock koncertov ter zvočnih performansov. Yan Junovega razvoja na področju zvočne umetnosti torej ni mogoče razumeti brez njegovega predhodnega ukvarjanja z dejavnostmi, ki so povezane z glasbo. Wang Jing (o njeni raziskavi več spodaj) je raziskala kitajsko zvočno umetnost s filozofskega vidika, moja razprava pa se predvsem osredotoča na Yan Junov osebni pogled na njegovo lastno umetnost in umetniški razvoj. Obenem pa razprava tudi izpostavlja Yan Junova etična načela, ki prežemajo vse dejavnosti, s katerimi se je ukvarjal oziroma se z njimi še vedno ukvarja.

Pričujoči članek sodi v okvir doktorske raziskave eksperimentalne elektronske glasbe v Pekingu, ki sem se jo pričel leta 2009 v okviru doktorskega študija na Oddelku za azijske in afriške študije Filozofske fakultete v Ljubljani. Zaradi pomanjkanja ustreznih pisnih virov, neposredno povezanih $\mathrm{z}$ raziskovalno temo, sem se odločil, da $\mathrm{v}$ sklopu desetmesečne terenske doktorske raziskave (od septembra 2010 do junija 2011) opravim z glasbeniki, relevantnimi za mojo disertacijo, intervjuje $\mathrm{v}$ kitajskem jeziku ( $\mathrm{v}$ pričujočem članku so prevedeni $\mathrm{v}$ slovenščino). Z Yan Junom, ki od leta 1999 živi v Pekingu (prej v mestu Lanzhou), sem se v ta namen srečal dvakrat: prvi intervju sva opravila 23.12.2010, drugega pa 29.5.2011.

Kar se tiče objektivnih pisnih virov, je težava predvsem $\mathrm{v}$ tem, da je področje eksperimentalne glasbe na Kitajskem in $\mathrm{v}$ Pekingu $\mathrm{s}$ strani akademskih raziskovalcev skrajno nezadostno raziskano. Edina celovita raziskava, osredotočena na področje zvočne umetnosti na Kitajskem, je doktorska disertacija $\mathrm{z}$ naslovom Making and Unmaking Freedom: Sound, Affect and Beijing, ki jo je junija 2012 uspešno ubranila Wang Jing, kitajska študentka na Ohio University v ZDA. Osrednja tema njene disertacije je svoboda in afektivno poslušanje v okviru kitajske zvočne umetnosti. Wangova se zvočne umetnosti na Kitajskem loti predvsem iz filozofske perspektive. Rezultate terenske raziskave interpretira na podlagi Deleuzeve in Guattarijeve filozofije, osrednji problem disertacije pa je vprašanje, kako je simbol svobode, prenesen $\mathrm{v}$ družbeno-kulturno ideologijo, 
vrednote in impulze, oblikuje in je oblikovan z družbeno-kulturnim okoljem, ki se pod vplivom globalizacije samo na sebi spreminja. (Wang 2012b, 3). V osebni korespondenci po elektronski pošti mi je Wangova povedala, da se je zaradi odsotnosti relevantne literature s področja zvočne umetnosti na Kitajskem tudi ona odločila za pridobitev ključnih podatkov s pomočjo intervjujev z relevantnimi zvočnimi umetniki. Eden od informantov in intervjuvancev je bil tudi Yan Jun.

Yan Junovo ime se sicer pojavlja v nekaterih razpravah o kitajski rock glasbi, a nikjer v vlogi zvočnega umetnika. Nekateri raziskovalci rock glasbe predvsem navajajo njegove zapise o tej zvrsti glasbe ali pa neposredno komunikacijo z njim (Groenewegen 2005; de Kloet 2010). Van Crevel (2008) ga opazuje v vlogi pesnika, medtem ko ga Campbell (2011) na kratko omeni kot glasbenega založnika. Jeroen de Kloet v svoji knjigi China with a Cut sicer omeni, da je Yan Jun umetnik $(2010,19)$, toda v nadaljnji razpravi nastopa Yan Jun zgolj v vlogi glasbenega kritika, ki ga de Kloet občasno navaja.

$\mathrm{Na}$ internetu je sicer mogoče najti ogromno zapisov, ki so na tak ali drugačen način povezani z Yan Junom (bodisi da gre za zapise o Yan Junu ali pa so objavljene domnevno njegove kritike, ob katerih pa ponavadi ne piše, kje in kdaj so bile objavljene). Večinoma gre za osebne bloge, ki so kot vir nezanesljivi zaradi pristranskosti. Kljub temu so bili nekateri podatki koristni za oblikovanje intervjuja. Vprašanje je bilo zastavljeno na način, da se je lahko Yan Jun izrazil glede tega, ali je določen podatek resničen ali ne.

Nekaj informacij o Yan Junu je moč najti tudi na spletni strani Pangbianr (pangbianr.com). Problem tega vira je, da je namen spletne strani predvsem promocija underground glasbenih skupin, zato so zapisi na njej pristranski in povečini nekritični. Josh Feola, urednik in pisec portala Pangbianr, je sicer članke, povezane z Yan Junom, objavil tudi drugje (npr. članek na glasbeni spletni strani Tiny Mix Tapes z naslovom 100 Flowers: Yan Jun), toda kljub temu je njegova umeščenost $\mathrm{v}$ kroge underground glasbenikov razlog za dvom $\mathrm{v}$ njegovo objektivnost, nepristranskost in kritičnost. ${ }^{1}$

Pri obravnavi zvočnega umetnika seveda ne gre brez glasbenih CD-jev. Problem, ki se tu pojavi, je pomanjkanje kritičnih recenzij. Kljub temu, da je Yan Jun nekaj svojih zvočnih del (predvsem terenskih posnetkov) izdal pri drugih založbah (npr. Lona Records, Soundpocket, idr.), je večino svojih del izdal pri

\footnotetext{
${ }^{1}$ Josha sicer poznam osebno in ne dvomim v njegovo poštenost, toda v prispevkih, ki jih objavlja na spletni strani pangbianr.com, piše o glasbenikih nekritično in pristransko.
} 
svoji založbi Kwanyin. Iz tega vidika je zato težko oceniti kvaliteto njegovih del oziroma njihovo relevantnost $\mathrm{v}$ prostoru kitajske eksperimentalne glasbe.

Zaradi neraziskanosti obravnavane teme in težav pri zbiranju objektivno naravnanih materialov, sem se $\mathrm{v}$ razpravi predvsem oprl na intervjuja, ki sem ju opravil z Yan Junom. Razprava je zanimiva za znanstveno javnost zato, ker ponuja vpogled na področje, ki še ni bilo deležno celovite akademske obravnave.

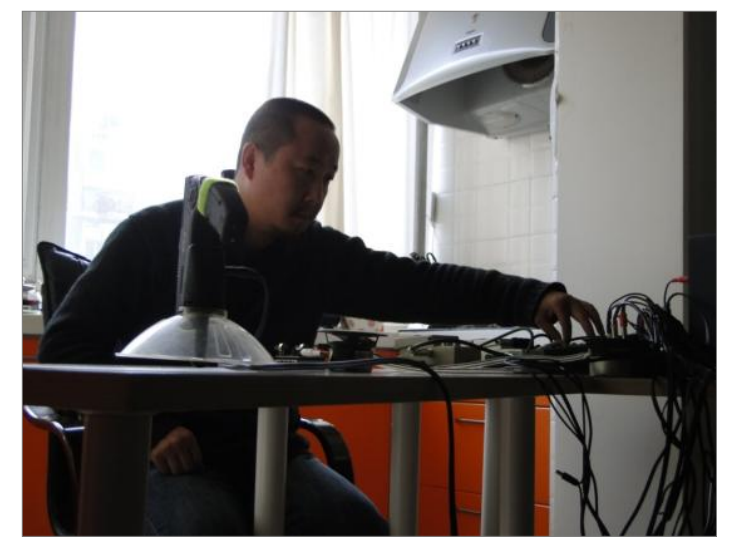

Fotografija 1: Yan Jun, Living Room Tour, Shan Studio, 8. januar 2011. Foto: Matic Urbanija

\section{Lanzhousko obdobje}

V svojem rojstnem mestu Lanzhou 兰州 je Yan Jun živel od rojstva leta 1973 do leta 1999, ko se je preselil v Peking. Ker je že od mladih let želel postati pesnik, se je vpisal na oddelek za kitajski jezik na Kitajski severozahodni univerzi (中国西北 大学) v Lanzhouju. Tako kot večina drugih kolegov na oddelku, tudi on ni maral hoditi na predavanja, ampak je večino časa bral knjige, se družil s študijskimi kolegi, hodil na recitale poezije ter spoznaval lokalne pesnike. Po zagovoru diplome leta 1995 se je zaposlil pri časopisu Lanzhouski večernik 兰州晚报, kjer je opravljal zadolžitve namestnika urednika za literarno sekcijo, pozneje pa je postal urednik te sekcije. Istega leta je nekaj mesecev pripravljal tedensko radijsko oddajo o rocku. Glasba, ki jo je predstavljal poslušalcem, se je, za takratne razmere, radikalno razlikovala od tiste, ki jo je bilo moč slišati v običajnem 
programskem terminu. Yan Jun je hotel predstaviti glasbo, ki je ljudje niso poznali, npr. Metallica, Alan Parsons Project, Godflesh, in druge. (intervju 2010)

Čeprav se nam v Evropi zdi, da so zgoraj naštete glasbene skupine znane večini ljudi, pa v 90-ih na Kitajskem ni bilo tako. Yan Jun razlaga, da so imeli dostop do te vrste glasbe zgolj tisti, ki so poznali preprodajalce ilegalnih CD-jev (t. i. dakou CD-ji). (intervju 2010) V 90. letih prejšnjega stoletja in $\mathrm{v}$ začetku enaindvajsetega stoletja so se namreč na Kitajskem črnem trgu pojavile zgoščenke popularnih tujih glasbenikov, ki so jih velike založbe zavrgle zaradi slabe kvalitete in jih poslale v reciklažo. Da bi preprečili ilegalno preprodajo takšnih zgoščenk, so jih na robu preluknjali (od tod izraz dakou 打口). Kljub temu pa so bile še vedno uporabne za poslušanje. Velike količine preluknjanih zgoščenk ni bilo uničenih, ampak so končale na kitajskem črnem trgu. Kar so na Zahodu zavrgli kot smeti, je na Kitajskem spodbudilo nastanek generacije, ki je glasbo spoznavala prek zavrženih zgoščenk (od tod tudi izvira ime za to generacijo, dakou generacija). (de Kloet 2010, 19-20) Yan Jun pove, da so prodajalci dakou CD-jev opravljali tudi funkcijo glasbenih poznavalcev, ki so svojim kupcem priporočali določeno glasbo in jih seznanjali z novostmi. Na ta način je Yan Jun prišel v stik z glasbo, ki so jo mainstream mediji večinoma ignorirali. (intervju 2010)

Jeroen de Kloet v uvodu svoje knjige China with a Cut: Globalisation, Urban Youth and Popular Music (naslov knjige nakazuje na preluknjane zgoščenke) navede Yan Junovo mnenje glede dakou generacije, ki jo je izrazil v spisu Večno mlad, večno objokan - Zapiski o Festivalu Midi 2002 (永远年轻, 永远热泪盈眭 -- 2002 迷笛音乐节记事 Yongyuan nianqing, yongyuan releiyingkuang - 2002 Midi yinyuejie jishi), objavljenem v zborniku esejev o rock kulturi Boemska Kitajska (波西米亚中国 Boximiya Zhongguo): dakou generacija »predstavlja generacijo, ki zavrača to, da bi bila zatrta, ki išče tisto, kar ni vidno, ki se povezuje z undergroundom, ki ustvarja marginalno kulturo in življenjski stil, ki trmasto raste ter se upira in bori.« (de Kloet 2010, 21; Yan 2004a, 157) De Kloet označi to Yan Junovo izjavo kot enostransko, ker zgolj slavi uporništvo, njegovo trditev glede subverzivnosti pa interpretira kot poskus izpostaviti marginalne tendence $\mathrm{v}$ času, ko so drugi opazovalci vso kitajsko realnost potisnili v okvir komercializacije, ki je utišala vsakršno kritiko. (de Kloet 2010, 21)

Yan Jun gleda na glasbeno sceno iz svojega zornega kota udeleženca $\mathrm{v}$ marginalni, underground sceni, najprej kot organizator koncertov in založnik za 
skupine, ki so bile v času po njegovem prihodu v Peking leta 1999, pa vse do leta 2003, ko je začel z ustvarjanjem zvočne umetnosti, v krogu marginalizirane scene.

\subsection{Yan Jun kot pesnik}

Yan Jun je začel pisati pesmi v srednji šoli, kar je bilo v tistem času med mladino zelo popularno. Njegove pesmi niso bile samo romantične, ampak včasih tudi kot pravi sam - malce čudne. Zelo pomembna zgleda sta mu bila pesnika Xi Chuan 西川 in Haizi 海子. V tistem času je redno prebiral revijo Shikan 诗刊 (Pesniška revija), ki mu je širila obzorja na področju pesništva in lastnega ustvarjanja. (intervju 2010)

Že zelo mlad sem bral knjige, zelo veliko knjig. Zelo rad berem knjige. [...] Prebiral sem tako tuje kakor tudi stare kitajske pesmi. Pa tudi sodobne. Toda bila je tudi Pesniška revija. Pozneje sem spoznal, da je konzervativna, a v tistem času [...] Pred letom 89 je bila namreč Kitajska zelo napredna. Takrat si lahko prebiral zelo različne zadeve, novo književnost. Bilo je veliko novih pesmi in književnosti. Modernistična, kitajska modernistična [književnost]. (intervju 2010)

Čeprav Yan Jun tega v pogovoru ni povedal eksplicitno, prav gotovo omenja leto 1989 kot prelomnico zaradi pokola na Trgu nebeškega miru 4. junija tega leta. Po pokolu se je namreč naprednost idej končala. Groenewegen $(2005,30$, op. 86) glede te prelomnice navaja Shija Anbina:

Mladi liberalni intelektualci v 80-ih letih so si z ožigosanjem maoistične agende kot »fevdalistične« ovire za modernizacijo Kitajske prizadevali za to, da se odpovedo revolucionarni zapuščini in namesto tega oživijo projekt intelektualcev gibanja 4. maja za razsvetljeno Kitajsko. Vendar pa se je njihova utopična ambicija končala $\mathrm{v}$ prelivanju krvi leta 1989 , pozneje pa je bila $\mathrm{s}$ pomočjo vsemogočne komercializacije in globalnega kapitalizma poznih 80-ih in zgodnjih 90-ih zavržena v pozabo. Preprosto povedano: če je $\mathrm{v}$ »novi dobi« [1978-1989] prevladoval visoki modernizem, je v »post novi dobi« začel rasti postmodernizem.

Mladi so po krvavi zadušitvi demonstracij izgubili predhodni idealizem, da bodo lahko aktivno sodelovali pri spreminjanju Kitajske na boljše (Baranovitch 2003, 44). Idealizem je v 90-tih dvajsetega stoletja zamenjalo potrošništvo in hlastanje za denarjem. V tem času je zrasla generacija, ki se jo običajno imenuje baling hou 八零后, se pravi edinci ('mali cesarji') rojeni po letu 1980. Za te so dogodki 4. 
junija 1989 pozabljena preteklost. Prioriteta jim je, da si v prid boljših kariernih možnosti prizadevajo za članstvo v kitajski Komunistični partiji. (de Kloet 2010, 22). Po mojem mnenju, gre $v$ tej luči razumeti tudi Yanovo izjavo o napredni Kitajski pred letom 1989.

Leta 1996 je Yan Jun objavil svojo prvo pesniško zbirko z naslovom 49 pesmi (诗四十九首) $)^{2}$, kjer je zbral pesmi napisane $\mathrm{v}$ študentskih letih (1992-1996). V tistem času se je začel oddaljevati od pesniških krogov in se je povezoval z rock glasbeniki. Kot pravi, se je v času študija udeleževal številnih pesniških recitalov in si prizadeval spoznati pesnike, ki jih je občudoval in oboževal. Uspelo mu je, da se je vključil v kroge lokalnih pesnikov, s katerimi se je pogosto srečeval in so se skupaj družili. Vendar pa je bil pozneje razočaran. (intervju 2010)

Problem pesniških krogov je osebnostna razcepljenost. [...] Veliko let pozneje sem bil vedno bolj v krogih rockerjev in vedno manj v pesniških. [...] Pesniški krogi so zelo malenkostni. Vsi so tudi jebeni pijanci in ženskarji. [...] To ni isto kakor rockersko ženskarstvo. Pri njih je ženskarstvo pač ženskastvo, zelo odprto. Ženskarstvo pesnikov pa je zelo hipokritično. [...] V svoji notranjosti so zelo čudni, konzervativni in mainstream, vendar pa se pretvarjajo, da so odpadniki. Pravzaprav pa so si vsi (bodisi z delom na univerzi, z ukvarjanjem $\mathrm{z}$ biznisom ali pa $\mathrm{z}$ delom $\mathrm{v}$ vladnih organih) izbrali zelo konzervativen način delovanja. Toda pesmi, ki jih pišejo, so kakor da so podobni odpadnikom, kot da so Bukowski in njemu podobni. Toda vse skupaj je lažno. (intervju 2010)

Kot pomemben vpliv na svoje pesniško ustvarjanje navaja nadrealizem:

V srednji šoli mi je bil zelo pomemben nadrealizem. Toda na voljo ni bilo kaj prida prevodov, zelo malo literarnih del. Prebral sem samo malo uvoda $\mathrm{v}$ nadrealizem in sem nato menil, da je nadrealizem zelo kul. S sošolci sem se lotil tega: pisanje brez prestanka, brez razmišljanja. Menim, da je imel v tistem času nadrealizem name zelo pomemben vpliv. (intervju 2010)

V 80-ih letih dvajsetega stoletja je prišlo na Kitajsko iz Zahoda veliko kulturnih vplivov in med njimi je bil tudi nadrealizem, katerega se je v svoji karieri lotil tudi Yan Junov zgodnji vzornik Xi Chuan (Lingenfelter 2008, 120). Prodor novih idej iz Zahoda je bil posledica odpiranja Kitajske po letu 1978. Vendar pa je poezija, ki je črpala navdih iz Zahoda in je opustila politično motivirano poezijo, zmedla in

\footnotetext{
${ }^{2} \mathrm{Na}$ Yan Junovi spletni strani (www.yanjun.org) je sicer med njegovo bibliografijo navedena tudi ta zbirka, a je zraven napisan podatek, da gre za fotokopirano izdajo (se pravi ne za natisnjeno) in da je izšla pri Lanzhouskem večerniku (兰州晚报), se pravi pri časopisu, kjer je bil Yan Jun urednik. Ko sem Yan Juna ob robu najinega prvega intervjuja (2010) vprašal, če se da dobiti še kakšen izvod, mi je odvrnil, da ne in da sploh ne ve, če ima on sam še svoj izvod.
} 
razjezila uradni establišment Komunistične partije. Takšne poezije, ki je imela "pozahodnjen« videz, se je kmalu oprijel naziv 'meglena poezija' (meng long shi 朦胧诗). V 90-ih letih pa so se pojavili pozivi $\mathrm{k}$ vrnitvi $\mathrm{h}$ kitajskim karakteristikam v poeziji. Na prelomu tisočletja se je to sprevrglo v debato o tem, kakšen jezik uporabiti v pesmih: jezik ljudskih množic ali intelektualno elitistični jezik. (Yeh 2008, 12-13)

Tudi tretja zbirka pesmi, Nemogoče (Bu ke neng 不可能), je izšla leta 2006 pri založbi Sub Jam. Dve leti pozneje je izšla tudi druga izdaja istoimenskega CD-ja (FM3 + Yan Jun + Wu Quan, 2008) s posnetkom recitala v Thinker Cafe, 8. aprila 2003. Branje pesmi je vključevalo nekatere pesmi iz zbirke, za zvočno ozadje sta poskrbela Zhang Jian in Christian Viraant (FM3). Prav tako je na CD-ju spremljevalni video, ki je bil prikazan na recitalu, in ga je z različnih posnetkov sestavil video (in pozneje zvočni ter filmski) umetnik Wu Quan.

Maghiel van Crevel, profesor za moderno kitajsko poezijo na univerzi Leiden, je prisostvoval dogodku in takole opisuje Yan Junovo poezijo:

Yan Juna je najbolj izkusiti na prizorišču kakršen je Thinker Cafe, kjer je imel svoj recital. Njegova pesem v prozi 'Proti vsem organiziranim prevaram' (Fandui yiqie you zuzhi de qipian), prikliče $\mathrm{v}$ misel nenavadno kombinacijo medtekstov [intertexts]: dela Allena Ginsberga in Williama Burroughsa, kakor tudi Xi Chuana, še posebej njegov Pozdrav (Zhijing). 'Proti...' in 'Pozdrav' sta si enaka v kitični strukturi, paralelizmih in občasno celo pod metaforiki. Asociativni preskoki v 'Proti...' so še ena značilnost, ki jo Yan Jun deli s Xi Chuanom [...] Intertekstualnost z Ginsbergom je najbolj očitna v Yan Junovi zagrizeni družbeno-politični in etični zavzetosti in njegovi anarhistični drži. (Crevel 2008, 467)

V tem kontekstu je Wu Quan na platnu predvajal video spremljavo, ki je vključevala prizore vojne $\mathrm{v}$ Iraku, medicinskega osebja, ki je oskrbovalo obolele za SARS-om in stavbe, ki so označene za rušenje (s pismenko 拆, chai). Ves recital je spremljala na trenutke umirjena, spet druge trenutke pa razburkana glasbena spremljava dueta FM3. (van Crevel 2008, 468)

\footnotetext{
${ }^{3}$ Vsi prevodi so avtorjevi.
} 
Pesniška zbirka Nemogoče je sicer zadnja ${ }^{4}$, ki jo je Yan Jun izdal. Na internetu je moč najti podatek, da se je udeležil leta 2011 pesniškega festivala v Rotterdamu. (Poetry International 2011)

Iz podatkov, ki so na voljo, in iz Yan Junovega pripovedovanja, je mogoče izluščiti, da sta predvsem pristnost in prava moralna drža tista, ki sta Yan Junu blizu. Samo v tem kontekstu gre razumeti njegovo mnenje glede naprednosti Kitajske pred pokolom na Trgu nebeškega miru: po tem dogodku ni več pristnosti in zavzetosti za spremembe in ustvarjalnost. ${ }^{5} \mathrm{~V}$ tem smislu gre razumeti tudi pesem 'Proti vsem organiziranim prevaram' ${ }^{6}$. Ne samo kot protest proti zatiranju svobodne misli, ampak tudi proti vojni (posnetki iz Iraka) in prisilnemu omejevanju človekove svobode (posnetki stavb, ki jim je usojeno rušenje). Maghiel van Crevel na tem mestu označi Yan Juna za anarhista in tudi to je eden od načinov za interpretiranje pesmi. Skozi pesem se vsako toliko časa pojavlja beseda 'nasprotujem' (fandui 反对) in za njo stvari, katerim nasprotuje (kapitalistični miselnosti, reklamam, na sredini zrezanim filmom, rock junakom, ...). V to vključi tudi nasprotovanje samemu sebi. Torej, zavračanje vsega, kar ljudi ločuje in razdružuje, pa četudi je to lastna miselnost, pokvarjena skozi ideologijo, ki jo vsiljuje družba in država. S tega vidika je povsem razumljivo njegovo odvračanje od zlaganih odnosov v pesniških krogih in njegovo oziranje $\mathrm{k}$ bolj pristnim rockerjem.

\section{Selitev v Peking}

Čeprav Yan Jun pravi, da se je leta 1999 preselil v Peking predvsem zaradi ženske, v katero je bil zaljubljen, pa je kljub temu, da mu ljubljene osebe ni uspelo osvojiti, ostal v mestu vse do danes. (intervju 2010)

Takrat v Pekingu ni bilo eksperimentalne glasbene scene, je bila pa zato že vzpostavljena underground rock scena. Yan Jun se je družil z rock glasbeniki, predvsem z rock skupinami Jezik (Shetou 舌头), NO, Muha (Cangying 苍蝇) in

\footnotetext{
${ }^{4}$ Svojo drugo pesniško zbirko Infrasonični zvok (次声波) je izdal leta 2001 pri svoji založbi Sub Jam, ki je antologija pesmi, napisanih med 1991 in 2000.

${ }^{5}$ Tudi Wang Jing $(2012 b, 51)$ podobno komentira Yan Junovo izjavo, da »po 4. juniju ni več glasbe, ki bi nekaj izražala.«

${ }^{6}$ Celotno besedilo pesmi je moč najti knjižici, ki se nahaja v ovitku CD-ja Nemogoče (FM3 +Yan Jun + Wu Quan. 2008 (1. izd. 2003)). Impossible 不可能. Peking: Kwanyin Records (1. izd. Sub Jam).
} 
Možganska napaka (Naozhuo 脑浊). Bendi, s katerimi se je družil so pretežno izvirali iz drugih kitajskih provinc. Yan Jun razlaga, da so bili člani teh bendov zelo revni. Odšli so od doma, niso našli dela, nihče jih ni podpiral, zato so vso svojo jezo in stisko prelili $\mathrm{v}$ glasbo. $\mathrm{S}$ tem so imeli nekakšen pridih revolucionarnosti. (intervju 2010)

Značilnost underground rock scene $v$ tistem času je bila predvsem kritična drža do kitajske družbe, glasbeni stili so bili zelo heterogeni, od novega vala pa do industrijskega noisa. Naklada njihovih CD-jev ponavadi ni presegla 30.000 kopij (za kitajske razmere zelo skromna naklada). (de Kloet 2010, 43) Underground (dixia 地下) je torej nekaj, kar je nasprotno uradnemu, mainstreamu in površinskemu. (Groenewegen 2005, 30)

Ob tem je potrebno poudariti, da se rock skupine, ki je postala sprejeta od mainstreama, ne obravnava več kot del undergrounda. Sprejetost od mainstreama pomeni predvsem sprejetost od množice (dazhong 大众). V nasprotju s tem pa underground rock ni množična zadeva, ampak operira na obrobju popularne kulture. (Groenewegen 2005, 37) To razliko je pomembno izpostaviti, Baranovitch namreč ugotavlja, da je bila rock glasba dogodki na Trgu nebeškega miru leta 1989 predvsem domena univerzitetnih študentov in marginalnih, underground boemskih krogov, po pokolu oziroma v 90-ih letih pa je postal moda urbane mladine (Baranovitch 2003, 35).

\subsection{Yan Jun kot glasbeni kritik}

Yan Jun si je največ veljave in ugleda pridobil s pisanjem glasbenih kritik. (Groenewegen 2005, 11) S pisanjem kritik je začel leta 1996 v Lanzhouju in s tem nadaljeval tudi v Pekingu vse do leta 2004. Pisal je za najrazličnejše revije, npr. Tongsu gequ 通俗歌曲 (Popularne popevke), Modeng tiankong 摩登天空 (Moderno nebo; tudi ime glasbene založbe), Yinyue tiantang 音乐天堂 (Glasbena nebesa), Shucheng (书城 Knjižno mesto), Yinyue shikong 音乐时空 (Čas in kraj glasbe), Dushu 读书 (Branje), Nanfang Zhonghua 南方中华 (Južna Kitajska), Shishang 时尚 (Moda), itd (intervju 2011). ${ }^{7}$

\footnotetext{
${ }^{7}$ Nekatere svoje glasbene kritike je izdal v knjižnih zbirkah: Tie xue yaogun 铁血摇滚 (Iron Blood Rock). Chengdu: 成都音像出版社 (1999); Neixin de zaoyin 内心的噪音 (Noises Inside). Peking: 外
} 
Začel je z revijo Yinyue shenghuo 音乐生活 (Music Life), ki je bila namenjena predvsem objavi člankov v zvezi s t.i. Xin yinyue 新音乐 ('novo glasbo') - zaradi cenzuriranja vsega, kar je nosilo oznako »rock 'n' roll«, so uredniki glasbenih revij s tem pojmom označevali vso zahodno popularno glasbo, od jazza, rocka pa do elektronske glasbe. Yan Jun je kmalu dobil ponudbe za pisanje kritik v drugih revijah. Glasba, o kateri je pisal, je bila za tisti čas in prostor tako obskurna, da uredniki sploh niso vedeli, o čem piše, in je imel zato veliko mero svobode pri izbiri tematike člankov. Yan Juna je nagnjenost do anarhističnih idej pripeljala do revije Pengke shidai 朋克时代 (Punk Generation). Revija je bila pomemben glasnik nezadovoljstva mladih nad razmerami na Kitajskem v 90-ih letih (obdobje pričetka brezglavega potrošništva) in nad mainstream družbo. Prav tako je delovala kot povezovalni člen domače punkovske subkulture ter jo umeščala $\mathrm{V}$ kontekst drugih punkovskih subkultur po svetu (Feola 2012, 2).

Ko se je Yan Jun po letu 2003 začel sam ukvarjati z ustvarjanjem eksperimentalne zvočne umetnosti in se je oddaljil od rock scene, je pisanje kritik počasi opustil. V zadnjih letih samo še občasno kaj napiše:

Pišem literarne zapiske za revijo moje žene. Pišem tudi za tajvansko revijo Današnja umetnost. Drugo pa ne. Moj pogoj je, ali mi boš dal veliko denarja ali pa mi pusti, da pišem, kakor jaz hočem pisati. Ponavadi pa revije ne želijo, da bi pisal po svoje. Ne pustijo mi, da bi pisal v skladu s svojim mišljenjem, pa tudi nočejo mi dati veliko denarja. Zato ni [iz tega] nič. Pa tudi časa nimam. Namreč, če bi pisal po lastnem mišljenju, bi napisal zelo hitro. Če pa bi mi dali veliko denarja, bi se pa tudi strinjal, da porabim veliko časa za pisanje. (intervju 2011)

Pisanje glasbenih kritik je po vsej verjetnosti prineslo Yan Junu največ prepoznavnosti: Groenewegen ga označi za »slavnega glasbenega kritika in pesnika« (Groenewegen 2005, 11), zbirke njegovih kritik so bile izdane pri nekaterih večjih kitajskih založbah. Prav poznavanje glasbe mu je (kot bomo videli pozneje) omogočilo, da je spoznaval eksperimentalno glasbo, ki ga je (kot bomo videli pozneje) po prihodu v Peking vedno bolj navduševala.

文出版社 (2001); Di di xia -- Xin yinyue qianxing ji 地地下一新音乐潜行记 (UnderGroundGround). Peking: 文化艺术出版社 (2002); Ranshao de zaoyin 燃烧的噪音 (Noises In-Burning). Nanjing: 江苏文艺出版社 (2004). 


\subsection{Yan Jun kot organizator koncertov in performansov}

Organiziranja različnih prireditev se je lotil že v srednji šoli (1986-1991) kot eden od vodilnih članov šolske mladinske organizacije. Skupaj $\mathrm{z}$ drugimi člani mladinske organizacije je bil odgovoren za pripravo literarnih tekmovanj, razstav, plesov, zabav, pevskih nastopov in pesniških recitalov. Prvi rock koncert je pomagal organizirati že leta 1993 in z organizacijo nadaljeval tudi po zaključku šolanja. (intervju 2010)

Sredi 90-ih je bil v Lanzhouju zgolj en klub, kjer so imeli rock glasbeniki možnost nastopanja: Double Hundred. Vendar pa se ga je držal slab (mafijski) sloves. Ko so bili Yan Jun in njegovi prijatelji skoraj žrtve streljanja, se tja niso vrnili nikoli več. Pozneje so Yanovi prijatelji odprli klub Rolling Stone, ki se ga je prav tako držal slab sloves, a je vseeno služil kot stičǐ̌če za nove ideje in bil primerna lokacija za rock skupine, ki so bile na turneji po Kitajski. Pozneje je prirejal koncerte v klubu Urban Express. Leta 1998 si je prizadeval prirediti festival, na katerem bi združil underground rock skupine iz vse Kitajske. Festival mu sicer zaradi neugodnih okoliščin ni uspelo realizirati, je pa zato izdal publikacijo Sub Jam, ki pomembno doprinaša k razumevanju razmer na underground rock sceni v tem obdobju. (Feola 2012, 2) Prvotni namen publikacije Sub Jam je bila v prvi vrsti predstavitev bendov, ki naj bi igrali na festivalu, nato pa še predstavitev rock scen v različnih mestih po Kitajski. (Wang 2012b, 78)

Z (so)organizacijo rock koncertov je sicer nadaljeval tudi po prihodu v Peking, vendar pa se je sčasoma usmeril na organiziranje performansov eksperimentalne glasbe. Leta 2005 je pričel $\mathrm{z}$ več let trajajočo serijo eksperimentalnih performansov Waterland Kwanyin 水陆观音, ki je vseskozi (do leta 2010, ko jo je zaključil) potekala v baru 2Kolegas v pekinškem predelu Chaoyang 朝阳. Eden od razlogov za pričetek serije je bil tudi ta, da je potreboval stalni prostor, kjer bi lahko nastopal in pilil svoje veščine (kot bomo videli pozneje, se je Yan Jun takrat že ukvarjal z zvočno umetnostjo). Po drugi strani, pravi Yan Jun, pa je hotel dati priložnost za nastopanje glasbenikom, zvočnim umetnikom in bendom, ki niso imeli možnosti nastopati drugje - pogosto zaradi stila glasbe, ki večinsko ni bil popularen. Glasbeni stili v okviru serije performansov so bili zelo raznoliki in program, ki ga je izoblikoval Yan Jun s sodelavci, se je močno razlikoval od ostale glasbene ponudbe $v$ Pekingu in je bil zato zelo privlačen za publiko, lačno novosti. Yan Jun pravi, da je bilo najbolj intenzivno obdobje serije v obdobju 2005-2006: 
Po tem obdobju pa je bilo tako, da ljudi ni bilo več tako veliko, ker so v Pekingu vsi podobni turistom. Če je kakšna stvar nova, jo gredo takoj gledat. Ko se je Waterland Kwanyin začel, je bilo to novo. V letih 05-06 je bila to najbolj »dbest« prireditev. Če si bil v Pekingu in si imel opravka z glasbo ali kulturo, a nisi vedel za Waterland Kwanyin, si bil »out«. Moral si iti tja. Takrat je poleti stalo pred vrati sto ljudi. Znotraj pa so bili takšni ljudje kot na primer Blixa Bargeld, Steve Barker, ljudje iz veleposlaništev in predsedniki društev založniške industrije. Ali pa zelo znani umetniki. Takrat v Pekingu nisi mogel videti na kupu toliko različnih ljudi. To je bil zelo uspešen »party«. Glasbeniki, književniki, umetniki, underground, »upground«, zelo uspešni ljudje, zelo običajni ljudje, vsi v enem prostoru. Ni bilo razlike, vsi so se dobro počutili. Ljudje so glede glasbe menili: »Wow, v Pekingu je tudi takšna glasba.« [...] Ves Peking je bil nezanimiv, Waterland Kwanyin pa je bil Berlin. Vendar pa se je mnogo ljudi na to navadilo. Šli so iskat nove stvari. Zares najbolj neuspešno pa je bilo, da nam ni uspelo izoblikovati kroga poslušalstva te vrste glasbe. [...] Mnogo ljudi je imelo rado vzdušje, vendar pa niso imeli zares radi glasbe. Dandanes sem mnenja, da ljudje potrebujejo toplino in mehkobo, ki je podobna občutku domačnosti. A to ne zadostuje. Ljudem sem dal toplino in mehkobo, ki je takšna kot občutek domačnosti, dal sem jim občutek anarhizma. V letih 05-06 je bil Waterland Kwanyin anarhizem, ki je uspel. Namreč lahko si videl, da so se vsi ljudje imeli med sabo radi. Toda anarhizem ni takšne vrste uspeh in je bila to lažna podoba. (intervju 2010)

Leta 2005 je začel sodelovati z 'Midi šolo za glasbo' (Midi yinyue xuexiao 音乐学 校 $)^{8}$, ki je vsako leto v parku Haidian organizirala vsakoletni rock festival Midi. Rezultat sodelovanja je bil dodatni oder na festivalu, imenovan Mini Midi, namenjen eksperimentalni in noise glasbi ter zvočni umetnosti. Yan Jun je prevzel naloge glasbenega organizatorja za ta oder. (Wang 2012b, 94, 175) Pozneje, leta 2008, se je odločil, da Mini Midi preseli na drugo lokacijo. Razlog je bil, da je glasna glasba z glavnega odra povsem preglasila eksperimentalno glasbo na malem odru. (intervju 2010)

Istega leta je bil festival Midi zaradi olimpijskih iger odpovedan. Yan Jun se je kljub temu odločil, da organizira Mini Midi. (intervju 2010) Tridnevni festival, ki je potekal pred in $\mathrm{v}$ baru 2Kolegas, je potekal v znamenju razstav, performansov zunaj in znotraj bara ter predavanj. (Wang 2012b, 94)

Vendar pa se je Yan Jun leto pozneje (2009) odločil, da tisto leto ne bo organiziral Mini Midi.

\footnotetext{
${ }^{8}$ Midi šola za glasbo je bila ustanovljena leta 1993. Na njej poučujejo igranje rocka, bluesa in jazza. Med učitelji so bili med drugim tudi člani zasedb Tangchao 唐朝 (Dinastija Tang) in Huxi 呼吸 (Dihanje). (Groenewegen 2005, 43).
} 
Želel sem si odpočiti. Leta 2008 sem se zelo utrudil, preveč je bilo uspešno. Zato sem razmišljal, če bom še naprej delal tako, se moram preobraziti v profesionalnega organizatorja. Imeti bi moral podjetje in moštvo. Cel dan bi moral biti na angleškem veleposlaništvu in na tujih kulturnih inštitucijah. Ves dan bi moral z ljudmi iz fundacij hoditi na kosila in sestankovati. Vsak dan bi imel veliko obveznosti. Ne mislim delati teh stvari. [...] V vsem hočem najti izbiro: ali z veliko denarja organizirati velik glasbeni festival ali pa živeti udobno in svobodno? Nazadnje sem si mislil: »Ne morem delati tako, nočem uspeha. Drugače bom izgubil svobodo.« Zato [sem] naslednje leto počival. (intervju 2010)

Izbira je torej bila: veliko denarja ali veliko svobode. Yan Jun je izbral slednjo možnost.

Leta 2010 je ponovno organiziral Mini Midi. Tokrat performansi niso potekali samo v Pekingu, ampak so šli sodelujoči glasbeniki na turnejo po nekaterih kitajskih mestih (Wang Jing se je te turneje udeležila in jo podrobno opisuje v 5. poglavju svoje disertacije). (intervju 2010)

Istega leta se je odločil, da preneha $\mathrm{z}$ organizacijo serije Waterland Kwanyin in išče drug prostor za performanse. Prostor, kamor bodo prišli ljudje prvenstveno poslušat glasbo. Yan Jun predvsem namerava izvajati performanse $\mathrm{v}$ manjših prostorih z manj ljudmi:

Zelo dolgo sem nameraval to prekiniti, pa nisem vedel kako zaključiti. Zato zdaj ne potrebujem Waterland Kwanyin, ampak proctor, kjer bodo ljudje lahko poslušali glasbo. To je $\mathrm{v}$ primerjavi $\mathrm{z}$ domačnostjo, toplino in nežnostjo še boljša zadeva, a tudi težja. Predvsem bi omogočala ljudem, da resnično poslušajo glasbo, pa še, da skozi glasbo komunicirajo drug z drugim. (intervju 2010)

Podobno kakor pri pesništvu se je Yan Jun tudi pri organizaciji koncertov in performansov oziral predvsem na prost in neoviran umetniški izraz. V serijo performanskov Waterland Kwanyin je tako vključil posameznike in skupine, ki zaradi svojega posebnega umetniškega izraza niso dobili priložnost. Glede vzdušja, ki je prevladovalo v prvih dveh letih, sicer pravi, da je moč občutek povezanosti in enakosti, ki je prevladoval med ljudmi različnih življenjskih usmeritev in družbene veljave, razumeti v smislu uspelega anarhizma, toda v isti sapi to označi za lažen občutek. Ljudi je na performanse predvsem privabljala noviteta samega dogodka, ki jih je nekaj časa omamljala, ko pa se je stvar »obrabila«, je prijeten občutek minil. Večina jih je odšla iskat nov »fiks«. Yan Jun si torej pri prirejanju performansov predvsem prizadeva ustvariti skupnost ljubiteljev eksperimentalne 
glasbe, skupnost podobno mislečih, ki se med seboj združujejo na enakopravni ravni in med seboj izmenjujejo ideje.

\subsection{Ustanovitev založb Sub Jam in Kwanyin Records 观音唱片}

Potreba po ustanovitvi založbe za izdajo glasbe underground rock skupin se je pokazala okoli leta 2001, ko je Yan Jun prijateljeval z nekaterimi underground rock skupinami (že omenjeni bendi Muha, NO in Možganska okvara). Vse so hotele izdati glasbene albume, toda področje underground rocka je bilo zelo majhno (glej razpravo o tem v razdelku o Yan Junovi selitvi v Peking) in velike založbe niso bile pripravljene izdajati CD-jev za skupine z malo poslušalstva. Zato se je Yan Jun odločil, da ustanovi majhno založbo, ki bo pokrivala ta segment glasbenega trga. (intervju 2010)

Za ime založbe je uporabil skovanko Sub Jam, ki je nastala leta 1998 za že omenjeno brošuro o kitajskem rocku, ki jo je v samozaložbi izdal v Lanzhouju. Kitajsko ime založbe je bilo Tie tuo 铁托:

Takrat sem intenzivno premišljeval o imenu založbe. Moja angleščina ni bila dobra. Založba tudi še ni imela kitajskega imena. Kar naenkrat pa sem se spomnil na Sub Jam. Takrat sem menil, da je »sub« zelo kul (subkultura, Sub Pop, Sub Rosa ${ }^{9}$, Subhuman ${ }^{10}$ ). Daje vzdušje undergrounda in je povezano z glasbo. Zveni zelo improvizirano. »Tie tuo« pa sem dodal pozneje. Menil sem, da potrebujem kitajsko ime in sem razmišljal: »OK, naj bo 'tie tuo'.« Namreč, rečemo: »To je zelo 'tie', to je zelo dobro.« Tuo pomeni podpornik, privrženec. Zato 'tie tuo' pomeni zvest privrženec. Beseda mi je bila všeč, zato sem jo uporabil. Ta beseda zato nima posebne zveze s Titom. (intervju 2010)

Yan Jun je delovanje svoje založbe opisal kot anarhistično: z glasbenimi skupinami ni podpisoval pogodb in umetnikom je prepustil popoln nadzor nad avtorskimi pravicami. Preprosto je zgolj hotel izdajati dobro glasbo, ki so jo igrali njegovi prijatelji. Po vzoru Sub Jama so se kmalu po vsej Kitajski oblikovale male založbe, ki so podobno kot druge male glasbene založbe po svetu dokazovale, da glasbeniki ne potrebujejo nujno velikih založb za izdajo svoje glasbe. (Campbell 2011, 147)

\footnotetext{
${ }^{9}$ Sub Pop je ime ameriške glasbene založbe. Sub Rosa pa belgijske glasbene založbe.

${ }^{10}$ Subhuman je nacistični izraz za ljudi iz »nižje rase« (Untermensch). Obenem je tudi naslov skladbe glasbene skupine Throbbing Gristle, ki je pomembno vplivala na Yan Junov glasbeni razvoj (zato zapis z veliko začetnico).
} 
V prvih letih je izdajal tudi knjige s poezijo, a sčasoma je spoznal, da je to preveč zamudno delo, ki vzame preveč časa. Zato se je preusmeril zgolj na izdajo CD-jev. Izdane albume so večinoma prodajali po malih glasbenih trgovinah (včasih tudi takih z dakou zgoščenkami). (intervju 2010)

Štiri leta pozneje je ustanovil znamko Kwanyin Records. Yan Jun pravi, da se je takrat začel ukvarjati z zvočno umetnostjo in so on ter njegovi prijatelji (FM3, Wang Fan) potrebovali okrilje, pod katerim bi lahko izdajali svojo glasbo. Hotel pa je narediti jasno ločnico med Sub Jamom in Kwanyin Records:

Začel sem namreč ustvarjati glasbo [...], ki ni bila elektronska glasba, tudi ne rock, pa tudi ne kaj drugega. Bila je abstraktna. Veliko več sem poslušal takšne vrste glasbe. Zvočno umetnost in podobno. Rad sem si tudi ogledal zvočne inštalacije in podobne zadeve. Razmišljal sem: »Moram pričeti z novo znamko, z drugačno znamko.« [...] Hotel sem jasno ločiti eksperimentalno glasbo in neodvisno glasbo. Menil sem, da bi Sub Jam še naprej izdajal neodvisno glasbo. Toda nisem dobro premislil celotne zadeve in sem kmalu spoznal, da je to nemogoče. Namreč, neodvisne glasbene skupine so hotele imeti tisoč ali pet tisoč kopij CD-jev. Potem pa jim je potrebno še pomagati pri organizaciji koncertov in podobnih zadev. Nisem imel ne časa, ne energije, ne zmožnosti, da bi se tega lotil. Zato je Sub Jam izdal samo 16 CD-jev. Danes samo še Kwanyin Records izdaja CD-je. Zato torej serijska številka na CD-jih ni več od Sub Jama, ampak od Kwanyin Records. Sub Jam je zgolj logo, ki ga dam na $\mathrm{CD}$ - pomeni domačnost in je družina. Znotraj družine pa se dogajajo različne stvari. (intervju 2010)

Kwanyin Records z leti je postala reprezentativna založba, ki z izdanimi CD-ji ponuja pregled dogajanja na pekinški oziroma kitajski eksperimentalni sceni. Svoj nazor o svobodi in prostem umetniškem izrazu, rešenih pravnih in ekonomskih spon, je Yan Jun vpletel tudi v delovanje svoje založbe, ime Sub Jam pa izraža njegovo zavezanost svobodnemu (improviziranemu?) ustvarjanju v undergroundu.

\section{Yan Jun kot zvočni umetnik}

Kot izpostavi Wang Jing, je bilo leto 2003 za kitajsko eksperimentalno glasbo zelo pomembno in odločilno. Takrat je taiwansko-ameriški zvočni umetnik Yao Dajuin pri založbi Post-Concrete izdal CD kompilacijo z naslovom CHINA - The Sonic Avant-Garde, kjer je zbral zvočne kompozicije 15 kitajskih umetnikov, ki so takrat delovali na področju zvočne umetnosti. Istega leta je Yao organiziral prvi kitajski mednarodni festival eksperimentalne glasbe, Sounding Beijing (Beijing shengna 
北京声纳). Ta festival je bil temeljni kamen za razvoj zvočne umetnosti na Kitajskem. (Wang 2012a, 86-87)

Tudi za Yan Juna je bilo leto 2003 ključno. Nad Kitajsko je visela grožnja SARS-a, Yan Junovi priljubljeni rock bendi so eden za drugim razpadali, njihovi člani so bodisi odšli »na potovanje«, iskat sami sebe ali pa so popolnoma opustili glasbeno delovanje. Yan Jun je na recitalih poezije bral svoje pesmi ob spremljavi katere od glasbenih skupin. Vendar pa je na recitalih vedno težje zagotovil glasbeno spremljavo. Ob enem je tudi bolj intenzivno poslušal eksperimentalno glasbo, zvočno umetnost in noise. Začel se je ogrevati za možnost, da bi sam ustvarjal zvočno umetnost (intervju 2010)

\section{1 Vplivi}

Med stvarmi, ki so vplivale na njegovo ustvarjanje, Yan Jun v prvi vrst izpostavi nadrealizem. V glasbenem smislu pa je njegov okus zelo šrok. Pri 17 letih je poslušal Cui Jiana, pozneje pa se je profesionalno ukvarjal s pisanjem glasbenih kritik. Najbolj je bil glasbenim vplivom izpostavljen po preselitvi v Peking. Takrat je poslušal raznovrstno glasbo, od popa do death metala. Poglavitno je bilo, da so bile stvari skrajne in temačne. Tako je na spektru glasbenih stilov poslušal stile, ki so se med sabo zelo razlikovali, npr. industrial (Einstürzende Neubauten, Laibach, Throbbing Gristle) in bolj »lažjo« glasbo (Cocteau Twins, Bauhaus, Nick Cave). Prav tako je užival v punku, rapu in death metalu. Pomembno mu je bilo, da je imela glasba pridih 'skrajnosti' (jiduan 极端) in 'temačnosti' (heian 黑暗). (intervju 2010)

Leto po selitvi v Peking (2000) je pogosto zahajal v klube, kjer se je vrtel brit pop in techno, vendar se je te glasbe kmalu naveličal. Priznava, da se je v tistem času glede glasbe preveč oziral na mnenje drugih. Sčasoma je začel intenzivneje poslušati eksperimentalno glasbo in noise (Merzbow, Aube, Otomo Yoshihide, John Zorn, Steve Reich). (intervju 2010)

\subsection{Yan Junov umetniški razvoj}

Yan Jun se je po eni strani lotil ustvarjanja zvočne umetnosti iz nuje (pomanjkanje ustreznih glasbenikov za spremljavo na recitalih poezije), po drugi strani pa ga je 
prav zanimanje za eksperimentalno glasbo napeljalo na željo po ustvarjanju lastnih kompozicij. Kupil je $\mathrm{MD}^{11}$ in mikrofon ter se odpravil po mestu snemat zvoke. Nato je pridobljeni material na nastopih kombiniral z že posnetim materialom na CD-jih uveljavljenih eksperimentalnih glasbenikov. S prijatelji se je loteval najrazličnejših glasbenih eksperimentov:

Z Zhang Jianom in Wang Fanom smo bili pogosto skupaj in smo se skupaj zabavali. [...] Bili smo $\mathrm{v}$ stanovanju. $\mathrm{V}$ en prostor smo postavili radio, $\mathrm{v}$ drugem prižgali televizor, $v$ tretji sobi je bil zvočnik, ki je predvajal glasbo, mi pa smo bili tu [v osrednjem prostoru], pili in delali zvoke. Nismo imeli občutka, da delamo glasbo. Mislili smo samo, da delamo zvoke. Mislil sem si: »To pa ni težko, zelo zanimivo. « Potem sem si kupil MD, majhen mikrofon in odšel snemat. Ko sem posnel zvoke, sem nastopal. Bilo je tako preprosto. Na oder sem prinesel MD in CD predvajalnik. V predvajalniku sem imel glasbo drugih ustvarjalcev. Eksperimentalno glasbo (npr. Sachiko $\mathrm{M}$ ali Johna Oswalda ${ }^{12}$ ) sem dal v CD predvajalnik, potem pa sem si zapisal na kateri minuti in sekundi je kakšna stvar. Potem sem to predvajal skupaj s svojimi posnetki (snemal sem avtomobile ali pa ljudi, ki so se pogovarjali). Potem sem prebral pesem. (intervju 2010)

Prvi performans je imel leta 2004 v Guangzhou. Posnetek je izdal pri (svoji) založbi Sub Jam ${ }^{13}$. Performans je izvedel skupaj z duetom Other Two Comrades 另外两位同志. Pravi, da prav ta nastop odraža njegovo razmišljanje o zvočni umetnosti v tem času. Kombinacija zvokov z živimi posnetki, ki so na trenutke zelo abstraktni, na trenutke pa humorni (npr. posnetek na vlaku, ko sprevodnica po zvočniku razlaga, katere jedi so na voljo $\mathrm{v}$ jedilnem vagonu). $\mathrm{Na}$ koncu performansa je prebral pesem. (intervju 2010)

Sčasoma, ko si je nabral dragocene izkušnje, je pri oblikovanju zvoka na svojih performansih uporabljal različne tehnike in pripomočke. V začetku so bili v ospredju predvsem sampli iz del drugih glasbenikov ter posnetki iz okolice, ki jih je zmešal skupaj. Toda sčasoma se je odločil, da bo sam ustvarjal zvoke. Težava je bila $\mathrm{v}$ tem, da ni znal igrati nobenega inštrumenta. Nekaj časa je uporabljal računalnik, toda tak način kreiranja zvoka in kompozicij ga ni privlačil:

Računalnik mi ni dal posebnega občutja. Poleg tega bi se moral zelo dolgo učiti kako ga uporabljati. Toda zelo sem len [...], ne len, nimam časa.

\footnotetext{
${ }^{11}$ MiniDisc

${ }^{12}$ Ironično pri tem je, da je prav John Oswald utemeljil koncept plunderphonics, se pravi, glasbenega kolaža sestavljenega iz delov kompozicij drugih glasbenikov.

${ }^{13}$ Other Two Comrades + Yan Jun. 2004. Live at Guangzhou 现场 广州. Sub Jam (CD).
} 
Kakorkoli, veliko je razlogov, zakaj mi je neprijetno uporabljati računalnik na nastopih. Menim, da glasba, ustvarjena $\mathrm{z}$ računalnikom, ni preveč dobra. Nekaj računalniške glasbe se mi zdi sicer dobro, toda pri njenem ustvarjanju ni istega občutka, ko delaš z rokami. (intervju 2010)

Zato se je oprijel drugih načinov kreiranja zvokov. Nekaj časa je uporabljal glasbene vilice, katerih zvok je preko mikrofona prenesel $\mathrm{v}$ mešalko in nato oblikoval nov zvok. Hkrati s spremembo tehnike in pripomočkov je prišlo tudi drugačno občutenje zvoka oziroma kvalitete zvoka. Yan Jun pripoveduje, da ima zelo rad stvari, ki so močne (you liliang 有力量), a ob enem poudari, da so lahko tudi mehke stvari zelo krepke:

Nekaj časa sem kreiral dolgo trajajoče zvoke. Ti so enako kot grleno petje zelo mistični. Imel sem rad njihovo mističnost. Pravzaprav je imelo to nekakšen religiozni učinek. [...] Hotel sem še bolj močne stvari. Mehke stvari so lahko še bolj močne kot trdne, lahke stvari so lahko še bolj močne kot težke. (intervju 2010)

Priznava, da se je na začetku preveč poglabljal v to, da bi bil zvok zelo konkreten, glasen, da bi ga ljudje razumeli. Pozneje se je predvsem usmeril v to, da je zvok čimbolj abstrakten. »Moja glasba je podobna velikemu prostoru... nadrealističnemu prostoru!« (intervju 2010)

Ob performiranju $\mathrm{z}$ glasbenimi vilicami in mikrofonom se je vedno bolj navduševal nad možnostmi, ki jih ponuja feedback in njegova modulacija na mešalki. Zvok je bil bolj abstrakten in manj povezan s kulturo. Dolgi zvoki, ki jih je kreiral do tedaj tako niso več zadostovali:

Menil sem, da še ni dovolj dobro. Tako je, nezadostno je bilo. Ko sem uporabljal glasbene vilice, sem uporabljal tudi mikrofon. Opazil sem, da mikrofon povzroča feedback. [...] Imel sem mikrofon in sem napravil feedback. Na primer, uporabljal sem najbolj nizkotonske glasbene vilice, 64 $\mathrm{Hz}$, feedback pa je bil zelo glasen, nizkotonski feedback. [...] Povezani dolgo trajajoči ton [...] še ni bil dovolj neposreden. Še vedno je zvenel preveč dobro. Oziroma drugače povedano, preveč glasbeno. Hotel pa sem imeti stvari, ki so manj glasbene. Hotel sem imeti čiste tone, bolj neposredno stvar. Dolgi ton [...] ni bil dovolj abstrakten. Ta zadeva je ljudem preveč domača. V smislu človeške kulture, jim je preveč blizu. Danes lahko jasno povem, zakaj takrat nisem hotel tega: zato, ker imam rad stvari, ki imajo malo ali pa nič kulturne reference. (intervju 2010)

Yan Jun poudarja, da namen zvokov, ki jih ustvarja ni, da bi bilo ljudem prijetno, ampak da bi jim bilo neprijetno (v to vključuje tudi sebe). V nasprotju z glasbeniki, 
ki ljudi drogirajo s sladkimi zvoki, ob katerih slednji pozabijo na svojo samoto, hoče Yan Jun ravno ljudi spodbuditi k zavedanju, da so na svetu sami. To je namreč temeljna resničnost našega bivanja. Pri tem ne gre za osamljenost, ampak samost. Četudi si obkrožen s prijatelji, se vrneš domov sam. In četudi te doma čaka partner/ica, si, preden zaspiš, zaziban v trenutek absolutne samote (Wang 2012a): »Samost pomeni, da si sam svoj, da ti ničesar ne manjka. Samost pomeni celovitost.« (Wang 2012a)

Veliko spremembo je Yanovi zvočni kreativnosti prinesla naprava za poslušanje $\mathrm{ptic}^{14}$. A tudi tu ni šlo brez težav, ki so Yana pripeljale v ustvarjalno stisko.

[...] Takrat sem za feedback začel uporabljati napravo za poslušanje ptic. Toda na začetku je bilo zelo težko. Tisti zvok je bil eeeeeeeeeeeeeeeeeeeeeee ${ }^{15}$. Zgolj ta zvok, zelo grozno. Na nastopih ni hotel nihče nastopati skupaj z mano. [...] Neprestano sem razmišljal kaj storiti. Zato sem občasno še vedno uporabljal glasbene vilice in kombiniral zvok še z glasom. V letih 2005-07 sem preizkusil vse možne načine. Leta 2007 sem zelo trpel: [...] Le kaj naj storim? Zvok naprave za poslušanje ptic je nezadosten in neuporaben, feedback pa je bil preveč monoton in predirljiv. (intervju 2010)

Toda ob koncu leta 2009 se je vsa zadeva izkristalizirala:

$\mathrm{Na}$ koncu se je vse počasi uredilo. Pravzaprav je bilo to lani ${ }^{16}$. Lani sem problem nazadnje le razrešil. Pred enim letom sem šele uredil [zadevo], jo izkristaliziral. Šele takrat sem imel inštrument, ki ga imam še danes. (intervju 2010)

Po letu 2009 je Yan Jun obvladal napravo za poslušanje ptic in jo vedno uporablja pri svojih performansih. Postala je njegov inštrument. Pri procesu iskanja inštrumenta se zelo dobro vidi napredovanje eksperimentalnega oziroma zvočnega umetnika, tako iz vidika uporabe tehnologije kakor tudi izboljševanja kvalitete zvoka (ravno z zmanjševanjem kvantitete zvoka se je izboljšala njegova kvaliteta). Pri tem Yan Jun uporablja različne metode ustvarjanja feedbacka, npr. postavitev kontaktnega mikrofona na membrano zvočnika, uporaba naprave za poslušanje ptic, no input mixer itd. Ob tem mnogokrat ne dela na performansu nič:

\footnotetext{
${ }^{14} \mathrm{Na}$ sliki, objavljeni na začetku tega prispevka, je moč to napravo videti na Yan Junovi desni strani.

${ }^{15}$ Yan Jun je z glasom zelo predirljivo zahreščal.

${ }^{16}$ Leta 2009.
} 
Med performansom mi je zelo všeč, če nič ne počnem. Zvok se sam od sebe spreminja. Naprava za poslušanje ptic je namreč mikrofon. Če ga postavim zraven sebe in se nekdo med poslušalci premakne, je zvok hoummmmm ${ }^{17}$. [...] To vpliva na feedback. V prostoru vsi zvoki vplivajo na feedback. Nič mi ni treba storiti. Pokimam z glavo in že se zvok spremeni. To mi je še posebej všeč. Zakaj rad performiram? Lahko gledam in lahko poslušam. Ni mi potrebno delati česa drugega. Ravno zaradi tega imam zelo rad performanse. Zato je najbolj pomembno, da sem našel svoj inštrument. (intervju 2010)

Ob pogovoru z Yan Junom je beseda nanesla tudi na način poslušanja, ki ga imamo ljudje. Yan Jun izhaja iz predpostavke, da smo ljudje živali in bi zato morali tudi poslušati na način, kakor poslušajo živali, brez povezanosti s kulturnimi referencami:

Zelo sem vesel, da lahko povem, zakaj kreiram takšno glasbo. Kot sem že povedal, smo ljudje živali in poslušamo enako kot živali in ne tako kot ljudje. Ni potrebno, da se obnašamo kot ljudje. (intervju 2010)

Še več, ob pogovoru o albumu Naj živijo krave ${ }^{18}$ pove nekaj bistvenih misli o svojem dojemanju zvokov, šumov, hrupov in noisa:

Pravzaprav je glede te zadeve tako, da imam zelo rad močne zadeve. Rad imam mehke, toda tudi močne. Najbolj pomembno pri tem albumu se mi zdi, da ima zelo plavajoče in zdravilno vzdušje. Občutje zelo močne trave. Ta album je zame drogeraška glasba, vendar pa je zelo močna. Je mistična, pa tudi močna. Punk. Tako da sedaj, ko kreiram glasbo, je včasih mirna, včasih pa glasna. Menim pa, da to ni pomembno. Zelo močno ali ne, zelo glasno ali mirno, zelo toplo in mehko, to sploh ni pomembno. [...] Nočem, da je ljudem prijetno in se počutijo varno. Rad bi, da glasba predstavlja izziv, da je mistična in je vedno boljša kot droga. Dobra droga ni trava, kokain ali kaj drugega. Dobra droga je zvok. Zvoki so v primerjavi z drogami veliko boljši. (intervju 2010)

Pri vplivu njegove kreacije zvokov na druge ljudi ima Yan Jun precej holističen pogled:

Mislim, da so ostali ljudje zgolj del mene samega. Ostali ljudje so del mojega kozmosa. Tudi jaz sem del kozmosa ostalih ljudi. [...] Če pa hočeš stvari delati dobro, se ne moreš ločiti od ostalih ljudi. [...] Ne moreš zapustiti ostalih ljudi. Tvoj zvok ne more biti ne slišan od ostalih ljudi. Nemogoče je, da bi sam doma kreiral zvoke, ampak moram z drugimi ljudmi vzpostaviti stik, sicer

\footnotetext{
${ }^{17}$ Yan Jun da od sebe zelo globok in gromek glas.

${ }^{18}$ Tie Guanyin duo 铁观音 (Wu Quan + Yan Jun). 2006. Viva la vaches. Kwanyin Records.
} 
zvok ni popoln. Moje kreacije morajo slišati ostali ljudje. [...] Šele takrat moj zvok resnično obstaja. (intervju 2010)

Rdeča nit pri Yan Junovem razvoju v vlogi zvočnega umetnika je prav gotovo težnja po čim večji abstraktnosti njegovega zvoka. To težnjo bi lahko povezali z njegovim navduševanjem $\mathrm{z}$ nadrealizmom $\mathrm{v}$ mladih letih, kakor tudi $\mathrm{s}$ svobodo umetniškega izraza in svobodo bivanja. Pot do svobode in svobodnega izraza pa ni lahka. To se kaže pri Yan Junu na dveh ravneh. Najprej je tu njegovo lastno iskanje primernega orodja (inštrumenta), ki bi mu omogočal umetniški izraz, ustrezen njegovim zvočnim preferencam. Druga raven se kaže na ravni zvoka, ki ga ustvarja, ter v učinku tega zvoka nanj in na poslušalce. Namen tega, da slednjim ne privošči ugodnega počutja na svojih performansih, je po mojem mnenju predvsem ta, da lahko človek šele preko osebnostne krize dojame svojo celostnost, tako na čustveni kakor racionalni ravni (pravzaprav sta obe ravni med sabo združene). Takšna interpretacija Yan Junovih namenov pri ustvarjanju zvokov pravilno, je dodatno potrjena $\mathrm{z}$ njegovim razumevanjem povezanosti $\mathrm{z}$ drugimi ljudmi, ki je korelativna in komplementarna.

Občutek, ki je neprijeten in ob enem osupljiv, sem doživel pri poslušanju kompozicije Viva la vaches. Dramatičen zvok je prodiral vame in me na trenutke paraliziral, moja glava pa ni bila več sposobna jasnega razmišljanja. Seveda je k temu pripomogla tudi povečana glasnost, toda marsikatera druga glasba/zvočna umetnost ne bi bila sposobna izvleči iz mene takšne reakcije. Vmesni premori v kompoziciji omogočajo, da si odpočije pred novim zvočnim napadom na čutila, občutke in racio.

\section{$5 \quad$ Zaključek}

Iz vsega povedanega lahko vidimo, da je vodilno načelo Yan Junovega delovanja omogočanje in ohranjanje svobode ter $\mathrm{s}$ tem nasprotovanje kakršnikoli vkleščenosti v kalupe, ki so namenjeni omejevanju človekovega prostega izraza. Ko sem Yan Juna glede mota Mini Midija 2008, »Noise is Free« vprašal, kaj to pomeni, mi je razložil, da »v prvi vrsti pomeni to, da je brezplačen, pomeni pa tudi svobodo.« (intervju 2011) ${ }^{19}$

\footnotetext{
${ }^{19}$ Podobno je odgovoril tudi, ko ga je o isti zadevi vprašala Wang Jing (2012b, 27).
} 
Že v svojem pesniškem izrazu se je Yan Jun nagibal k nadrealizmu in pisanju v skladu s tokom zavesti, ki sta mu omogočala bolj svoboden izraz, osvobojen spon pravil metrike, ki naj bi jo moral pesnik upoštevati pri pesnjenju. Tudi pesem 'Proti vsem organiziranim prevaram' izraža nasprotovanje vsemu, kar ljudi razdružuje in jih dela nesvobodne. Sem sodi tudi njegov odmik od pesniških krogov. Spoznal je, da so pesniki, s katerimi se je družil, ujeti med težnjo po svobodi in prostovoljno ujetostjo v spone življenja, ki je podrejen diktatu družbe.

Tudi pri glasbenem založništvu in organizaciji performansov so vidne njegove tendence k omogočanju čim boljšega svobodnega izraza. Avtorjem je popolnoma prepustil vse avtorske pravice in jim prepustil popolno svobodo umetniškega ustvarjanja. Obenem je delovanje v undergroundu omogočalo do določene mere osvoboditev od »organiziranih prevar«. Na to nakazuje tudi ime založbe Sub Jam: svobodna improvizacija v undergroundu. Pri organizaciji performansov je dal možnost nastopanja predvsem ljudem, ki so bili zaradi svojega posebnega umetniškega izraza izključeni iz mainstream glasbenih dogodkov. A po dveh letih je bil razočaran. Pravzaprav bi lahko njegovo razočaranje interpretirali na način, da je Yan Jun spoznal nesvobodo drugih ljudi, ki so ujeti v iluzijo bleščečih novitet in so s tem že tako zadrogirani, da se določene stvari zelo hitro naveličajo, in potrebujejo vedno nekaj novega.

Princip svobode je izražen tudi v Yan Junovi zvočni umetnosti, predvsem iz vidika njegovega umetniškega razvoja. Od leta 2003 do 2009 je iskal primerno orodje (inštrument), s katerim bi lahko svobodno in brez omejitve izražal svoje dojemanje zvoka. Obenem pa si prizadeva sebe in svoje poslušalce vsaj za trenutek osvoboditi samih sebe in se v polnosti dojeti.

Poleg prizadevanja za svobodno umetniško in osebnostno izražanje, pa je zelo očitna rdeča nit, ki povezuje vse dejavnosti, s katerimi se je ukvarjal Yan Jun, glasba. Pri tem je opaziti trend, da je njegov glasbeni okus z leti postajal vedno bolj abstrakten. Začel je s Cui Jianom in nadaljeval z Zahodno rock glasbo ter rock glasbo lanzhouskega in pekinškega undergrounda. Pisal je kritike o rock glasbi in organiziral rock koncerte. Toda sčasoma, po selitvi v Peking leta 1999, se je začel bolj zanimati za bolj abstraktno, eksperimentalno glasbo, ki mu je bila verjetno zelo dobra podlaga in vodilo za lastno zvočno ustvarjanje. ${ }^{20}$

\footnotetext{
${ }^{20} \mathrm{Ta}$ interpretacija izvira predvsem iz moje lastne izkušnje poslušanja glasbe. $\mathrm{V}$ otroštvu sem poslušal pop glasbo, pozneje rock glasbo, danes pa poslušam bolj abstraktno, neplesno elektronsko glasbo (IDM, glitch, občasno tudi noise).
} 
Pričujoči članek vsekakor ni zaokrožen pogled na Yan Junovo ustvarjanje. Problem je, kot sem že omenil v uvodu, povsem nezadostna raziskanost področja eksperimentalne glasbe na Kitajskem. Zato upam, da bo ta članek predvsem služil za dobro izhodišče tistim, ki se bodo lotili nadaljnjih raziskav na tem področju.

\section{Summary}

The purpose of this article is to research artistic development of a sound artist Yan Jun, which cannot be understood without his previous life, before he became sound artist. In this sense, the primary notion through his life is the notion of freedom which is also the basis that can be traced through his interpretation of his own sound art. The article also puts forward Yan Jun's ethical principles which are leading principles in all his endeavors. Experimental music scene in China is, from academic point of view, under-researched and researches in this field are almost nonexistent, therefore, the primary source of information are two interviews made with Yan Jun in December 2010 and May 2011.

\section{Literatura:}

Baranovitch, Nimrod. 2003. China's New Voices: Popular Music, Ethnicity, Gender and Politics, 1978-1997. Berkeley: University of California Press.

Campbell, Jonathan. 2011. Red Rock: The Long, Strange March of Chinese Rock \& Roll. Hong Kong: Earnshaw Books.

de Kloet, Jeroen. 2010. China with a Cut: Globalisation, Urban Youth and Popular Music. Amsterdam: Amsterdam University Press.

Feola, Josh. 2012. '100 Flowers: Yan Jun.' Dostop: 14.10.2012. http://tinymixtapes.com/column/100-flowers-yan-jun?page=1.

Groenewegen, Jeroen. 2005. 'Making Sense of Underground Rock, Beijing 1994-2004.' Magistrska naloga. Leiden: Universitet Leiden.

Lingenfelter, Andrea. 2008. 'Opposition and Adaptation in the Poetry of Zhai Yongming and Xia Yu.' V: New Perspectives on Contemporary Chinese Poetry, uredil Christopher Lupke, 105-20. New York: Palmgrave Macmillan.

Poetry International \#42. 2011. 'Festival Blog (Yan Jun).' Dostop 14.10.2012. http://www.poetryinternationalblog.org/2011/?tag=yan-jun.

van Crevel, Maghiel. 2008. Chinese Poetry in Times of Mind, Mayhem and Money. Leiden: Brill. 
Wang Jing, Adel. 2012a. 'Guest Edition \#2 Adel Wang Jing/Yan Jun.' Dostop 14.10.2012. http://earroom.wordpress.com/2012/01/09/guest-edition-2-adel-wang-jingyan-jun/.

— 2012b. 'Making and Unmaking Freedom: Sound, Affect and Beijing.' Doktorska disertacija. Athens: Ohio University.

Yan, Jun. 2004a. 'Yongyuan nianqing, yongyuan releiyingkuang - 2002 Midi yinyuejie jishi' 永远年轻, 永远热泪盈眀 -- 2002迷笛音乐节记事 ('Večno mlad, večno objokan - Zapiski o Festivalu Midi 2002'). V: Bohemian China 波西米亚中国, uredil Liao Weitang 廖伟棠. Guizhou: 广西师范大学出版社.

—. 2006. Impossible 不可能. Peking: Sub Jam.

Yeh, Michelle. 2008. 'There Are no Camels in the Koran: What Is Modern about Modern Chinese Poetry?' V New Perspectives on Contemporary Chinese Poetry, uredil Christopher Lupke, 9-26. New York: Palmgrave Macmillan.

\section{Glasbeni materiali}

FM3 +Yan Jun + Wu Quan. 2008 (1. izd. 2003). Impossible 不可能. Peking: Kwanyin Records (1. izd. Sub Jam) (CD).

Other Two Comrades + Yan Jun. 2004. Live at Guangzhou 现场 广州. Sub Jam (CD).

Tie Guanyin duo (Wu Quan + Yan Jun). 2006. Viva la vaches 杀不死的牛. Kwanyin Records (CD).

\section{Vir}

Intervjuja z Yan Junom (v kitajskem jeziku), opravljena 23.12.2010 in 29.5.2011 na Yan Junovem domu v Pekingu. 